\title{
FACTORS ASSOCIATED TO UNHEALTHY SEXUAL BEHAVIOURS AMONG PORTUGUESE ADOLESCENTS: 2018 HBSC STUDY
}

\author{
Lúcia Ramiro, Marta Reis, Margarida Gaspar de Matos \\ University of Lisbon, Portugal \\ E-mail: lisramiro@sapo.pt, reispsmarta@gmail.com, margaridagaspar@netcabo.pt
}

\begin{abstract}
Practicing sexual intercourse (SI) under the influence of alcohol or drugs has been identified as an unhealthy sexual behaviour. The sample consisted of 5695 adolescents, of which $46.1 \%$ were males, with a mean age of 15 years old. The measures consisted of asking the adolescent if he or she had ever had SI, age of $1^{\text {st }}$ SI, condom use at last SI, SI under the influence of alcohol or drugs and HIV testing. Most adolescents reported having never had SI (77.0\%). Among those who responded affirmatively, they referred having had their $1^{\text {st }}$ SI at 15 years old. A significant minority reported not having used condom at last SI (34.1\%) and having had SI under the influence of alcohol or drugs (14.5\%). It was noticeable that males, adolescents with high SES, those who reported not having used condom at last SI, those not having been HIV tested, those who consider themselves fat, smoke daily, and scored lower in emotional sensitivity and quality of life were those who were more likely to have reported having had SI under the influence of alcohol or drugs. Adolescents who reported having had SI under the influence of alcohol or drugs have multiple risk behaviours. These results may account for important changes in educational and health policies, directed towards the development of personal and social skills, the importance of adolescents ' quality of life and the activation of all the support structures where adolescents are involved and that are somewhat responsible for promoting a healthy lifestyle.
\end{abstract}

Keywords: unhealthy sexual behaviour, sexual intercourse, substance use, Portuguese adolescents

\section{Introduction}

A healthy lifestyle reduces the risk of being ill or dying early. Scientific studies have identified behaviours that jeopardize people's health and mental and social well-being. The prevalence of mental health difficulties has been growing, as accounted for by the rise of psychological symptoms in adolescents in HBSC studies (Matos \& Equipa Aventura Social, 2018). Thus, emphasis should be given on universal prevention programmes at school context within the framework of a public health policy. As such, lifestyles - both healthy and unhealthy - and the quality of life of children and adolescents are crucial to tailor effective intervention programmes (Taylor et al., 2017). In addition, the relationship between quality of life and overall well-being and several behaviours related to (un)healthy lifestyles such as physical activity, smoking, alcohol consumption, and truancy, among others, help identifying areas that should be specifically addressed through intervention (Gaspar et al, 2019). 
OF PSYCHOLOGY

IN THE $21^{\text {st }}$ CENTURY

Vol. 15, No. 2, 2021

74

In fact, childhood and adolescence are considered to be important developmental phases in terms of prevention and intervention for mental health and well-being (Collins \& Dozois, 2008).

Practicing sexual intercourse (SI) under the influence of alcohol or drugs is identified as an unhealthy sexual behaviour, mainly for adolescents, on the one hand due to their difficulty in assessing negative results as unwanted pregnancy and HIV/AIDS or other STI, and on the other hand due to the impact that these consequences may have in their lives (UNAIDS, 2018). According to the latest statistical data from UNICEF, worldwide, about 30 teenagers among 15 and 19 years old were infected with HIV/AIDS every hour in 2017. These numbers are particularly alarming if considered that the epidemics is consistently decreasing in all other age groups (UNICEF, 2018). In Portugal, about a third of those infected (with HIV/AIDS) is less than 30 years old and, among these, about $16 \%$ are between 15 and 24 years old. (DGS, 2018). The most effective method against most STIs (including HIV/AIDS) is still the condom.

Having SI associated to the consumption of alcohol or drugs has been identified as an unhealthy sexual behaviour (Madkour et al., 2010), since both alcohol and drugs alter one's levels of rationality and disinhibition. Moreover, alcohol and drug use has even more damaging consequences for adolescents because psychosocial development is still happening during adolescence (López \& Fuertes, 1999). As stated in the last national Health Behaviour in School-aged Children study (2018), both alcohol and drug consumption have been increasing in Portugal: daily consumption of spirits has increased from $0,4 \%$ (1998) to 3,7\% (2018), daily consumption of beer has increased from $1,0 \%$ (1998) to 3,6\% (2018); and drug consumption (more than once) in the last month has increased from $1,4 \%$ (1998) to $2,1 \%$. In Portugal, studies addressing SI under the influence of alcohol or drugs, and the factors associated with it in adolescents are scarce. Therefore, the aim of this study was to better understand unhealthy sexual behaviours and to shed light on the risk factors associated to these behaviours.

\section{Research Methodology}

\section{General Background}

The Health Behaviour in School-aged Children (HBSC) is a World Health Organization (WHO) collaborative cross-national study (Roberts et al., 2009) which is carried out every 4 years simultaneously in 50 countries or regions of Europe and North America in order to study school-aged behaviour regarding health and risk behaviours in adolescence (http://www.hbsc.org/). Portugal is part of this group since 1996 (www.aventurasocial.com).

\section{Sample}

The 2018 HBSC study included 8215 students from 42 schools and 476 classes, randomly selected, with a mean age of 14.36 years old $(S D=2.28), 52.7 \%$ of which are female, from the 5 educational regions of mainland Portugal. Results are representative of 6th, 8th 10th and 12th grade students.

Because the topic being studied is focused on SI, $6^{\text {th }}$ graders were excluded and therefore the sample was constituted by 5695 adolescents, of which $46.1 \%$ are boys and $53.9 \%$ girls, with a medium age of 15.46 years old $(S D=1,80)$. The majority is Portuguese $(91.7 \%)$. As for school grade, $48.6 \%$ attended 8 th grade, $30.0 \%$ attended 10 th grade and $21.4 \% 12$ th grade and they are proportionally distributed among the 5 educational regions of mainland Portugal (North, Centre, Lisbon and Tagus Valley, Alentejo and the Algarve).

In Portugal the 2018 HBSC study was approved by the Ethics Committee and the MSS (Monitoring Surveys in the School). Schools agreed to participate, and informed consent was obtained from parents or legal tutors of the students. The survey was conducted online, and the responses were voluntary and anonymous. 
Measures and variables

In order to pursue the stated aim, several questions of the protocol were used. As for the demographic questions, gender, school grades and socioeconomic status were used. And regarding the questions about sexual behaviours and specifically unhealthy sexual behaviours, the following were used: age of first SI, condom use at last SI, engaging in SI under the influence of substances and having been HIV tested were also asked among those who responded that they had already had SI. In order to study potential factors associated to unhealthy behaviours among adolescents, condom use at last SI, HIV test as well as other items related to unhealthy behaviours were selected, namely socioeconomical status, body image, physical activity, tobacco consumption, perception of academic performance, truancy, bullying, a scale of emotional insensitivity and a scale of quality of life. More information about the measures can be found in table 1 .

\section{Table 1}

Description of the Variables Included in the Study $(n=5695)$

\begin{tabular}{|c|c|c|c|}
\hline $\begin{array}{c}\text { Study } \\
\text { variables }\end{array}$ & Coding & Recoding & $\begin{array}{l}\text { Cronbach's } \\
\text { Alpha }\end{array}$ \\
\hline Gender & 1=Male; 2= Female & - & - \\
\hline School grade & $1=8^{\text {th }}$ grade $; 2=10^{\text {th }}$ grade $3=12^{\text {th }}$ grade & - & - \\
\hline $\mathrm{SI}$ & $1=Y e s ; 2=$ No & - & - \\
\hline Age of first SI & $\begin{array}{l}1=11 \text { years old or younger; } 2=12 \text { years } \\
\text { old; } 3=13 \text { years old; } 4=14 \text { years old; } 5= \\
15 \text { years old; } 6=16 \text { years old or older }\end{array}$ & $\begin{array}{l}\text { Item } 1 \text { was recoded into } 11 \text {; item } 2 \text { was } \\
\text { recoded into } 12 \text {; item } 3 \text { into } 13 \text {; item } 4 \text { into 14; } \\
\text { item } 5 \text { into 15; and item } 6 \text { into } 16\end{array}$ & - \\
\hline $\begin{array}{l}\text { Condom use } \\
\text { at last SI }\end{array}$ & $1=$ Yes; $2=\mathrm{No} ; 3=$ I don't know & $\begin{array}{l}1=Y e s ; \text { Items } 2 \text { and } 3 \text { were recoded into } \\
2=\text { No/l don't know }\end{array}$ & - \\
\hline $\begin{array}{l}\text { Sl associated } \\
\text { to alcohol or } \\
\text { drugs }\end{array}$ & 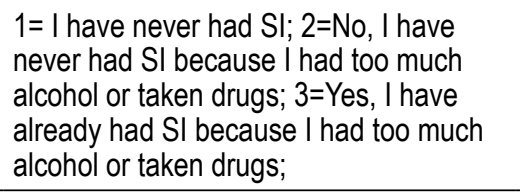 & $\begin{array}{l}\text { Item } 3 \text { was recoded into } 1=Y e s ; \text { Items } 1 \text { and } 2 \\
\text { were recoded into } 2=\text { No }\end{array}$ & - \\
\hline HIV test & $\begin{array}{l}\text { 1=Yes; } 2=\mathrm{No} ; 3=\mathrm{I} \text { don't know; } 4=\text { I don't } \\
\text { know what a HIV test is; }\end{array}$ & $\begin{array}{l}1=\text { Yes; Items } 2,3 \text { and } 4 \text { were recoded into } \\
2=\text { No/ I don't know/I don't know what a HIV } \\
\text { test is }\end{array}$ & - \\
\hline SES & $\begin{array}{l}\text { The SES consists of } 6 \text { items, which } \\
\text { reflect the family resources: family car } \\
(0=\text { No; } 1=\text { Yes, one; } 2=\text { Yes, two or } \\
\text { more), bedroom ( } 0=\text { No; } 1=\text { yes), number } \\
\text { of computers ( } 0=\text { none; } 1=\text { one; } 2=\text { two; } \\
3=\text { more than two), number of bathrooms } \\
\text { ( } 0=\text { none; } 1=\text { one; } 2=\text { two; } 3=\text { more than } \\
\text { two); dishwasher machine ( } 0=\text { No; } 1= \\
\text { Yes) and number of family vacation trips } \\
(0=\text { none; } 1=\text { one; } 2=\text { two; } 3=\text { more than } \\
\text { two). }\end{array}$ & $\begin{array}{l}\text { The SES score is calculated based on the } \\
\text { responses of the participants to these } 6 \\
\text { items on a 3-point ordinal scale composed } \\
\text { for analysis, where a low SES corresponded } \\
\text { to a score that ranges from } 0 \text { to } 6 \text { points; a } \\
\text { medium SES corresponded to a score that } \\
\text { ranges from } 7 \text { to } 12 \text { points; and a high SES } \\
\text { corresponded to a score that ranges from } 13 \\
\text { to } 18 \text { points }\end{array}$ & - \\
\hline $\begin{array}{l}\text { Body } \\
\text { perception }\end{array}$ & $1=$ Very thin to $5=$ Fat & $\begin{array}{l}\text { Items } 1=\text { Very thin; } 2=\text { Somewhat thin and } 3= \\
\text { Right size were recoded into } 0=\text { Right size/ } \\
\text { thinness; and the items } 4=\text { Somewhat fat and } \\
5=\text { Fat were recoded into } 1=\text { Fat }\end{array}$ & - \\
\hline $\begin{array}{l}\text { Physical } \\
\text { activity }\end{array}$ & $0=0$ days to $7=7$ days & $\begin{array}{l}\text { Item } 0=\text { never, all the other items were } \\
\text { recoded into } 1=\text { At least once a week }\end{array}$ & - \\
\hline
\end{tabular}


OF PSYCHOLOGY

IN THE $21^{\text {st }}$ CENTURY

Vol. 15, No. 2, 2021

76

\begin{tabular}{|c|c|}
\hline $\begin{array}{c}\text { Study } \\
\text { variables }\end{array}$ & Coding \\
\hline
\end{tabular}

\begin{tabular}{|c|c|c|c|}
\hline $\begin{array}{l}\text { Tobacco } \\
\text { consumption }\end{array}$ & $1=$ Never to $7=30$ days (every day) & $\begin{array}{l}\text { Items } 1 \text { to } 6 \text { were recoded into } 0=\text { not smoking } \\
\text { every day; and item } 7=30 \text { days was recoded } \\
\text { into } 1=\text { smoking every day }\end{array}$ & - \\
\hline $\begin{array}{l}\text { Academic } \\
\text { performance }\end{array}$ & $\begin{array}{l}1=\text { Very good to } 4=\text { Lower than the } \\
\text { average }\end{array}$ & $\begin{array}{l}\text { Items } 1=\text { Very good; } 2=\text { Good; and } 3=\text { Average } \\
\text { were recoded into } 0=\text { Higher than the } \\
\text { average; and item } 4=\text { Lower than the average } \\
\text { was recoded into } 1=\text { Lower than the average }\end{array}$ & - \\
\hline Truancy & $\begin{array}{l}\text { 1=I never miss a class except if I am } \\
\text { ill or for some unexpected event. } 2=I \\
\text { occasionally miss classes even if I am } \\
\text { not ill and there isn't any unexpected } \\
\text { event; } 3=\text { I miss classes for no special } \\
\text { reason, just because I feel like it or } \\
\text { because I'm late; } 4=\text { I miss classes for } \\
\text { other reasons }\end{array}$ & $\begin{array}{l}\text { Item } 1 \text { was recoded into } 0=I \text { never miss } \\
\text { classes; and items 2, } 3 \text { and } 4 \text { were recoded } \\
\text { into } 1=\text { Missing class }\end{array}$ & - \\
\hline Bullying & $\begin{array}{l}1=\text { I didn't bully anyone at school the } \\
\text { last two months; } 2=\text { It happened once } \\
\text { or twice in the last } 2 \text { months; } 3=2 \text { or } 3 \\
\text { times a month; } 4=\text { About once a week; } \\
5=\text { Several times a week }\end{array}$ & $\begin{array}{l}\text { Item } 1 \text { was recoded into } 0=I \text { didn't bully; and } \\
\text { items } 2,3,4 \text { and } 5 \text { were recoded into } 1=\text { at } \\
\text { least one time }\end{array}$ & - \\
\hline $\begin{array}{l}\text { Emotional } \\
\text { insensitivity }\end{array}$ & $\begin{array}{l}\text { Scale with } 6 \text { items, with Likert response } \\
\text { options: } 1=\text { I totally agree to } 5=\text { totally } \\
\text { disagree }\end{array}$ & $\begin{array}{l}\text { The scale assesses emotional insensitivity } \\
\text { and consists of } 6 \text { items. Items } 1,2 \text { and } 5 \\
\text { were reverse scored; scores ranged from } 6 \\
\text { to } 30 \text {; higher values reveal more emotional } \\
\text { insensitivity. }\end{array}$ & .64 \\
\hline $\begin{array}{l}\text { KIDS (quality } \\
\text { of life) }\end{array}$ & $\begin{array}{l}\text { Scale with } 10 \text { items, with response } \\
\text { options } 1=\text { never, } 2=\text { rarely, } 3= \\
\text { sometimes, } 4=\text { often and } 5=\text { always }\end{array}$ & $\begin{array}{l}\text { The scale assesses quality of life and consists } \\
\text { of } 10 \text { items with a response option ranging } \\
\text { from } 1 \text { = poor quality of life to } 5=\text { good quality } \\
\text { of life; scores ranged from } 10 \text { to } 50 \text {; Items } \\
3 \text { and } 4 \text { were reverse scored; higher values } \\
\text { indicated very good quality of life. }\end{array}$ & .84 \\
\hline
\end{tabular}

Procedures

This study is based on data from the Health Behaviour in School aged Children/HBSC (Inchley et al., 2016; Matos et al., 2015, 2018), a collaborative WHO study.

It aims to study adolescent behaviour in their various settings and how these influence their well-being. A broad set of topics are studied, namely family, school, friends, health, well-being, sexuality, nutrition, leisure, sleep, sedentarism, physical activity, substance use, medicine use, violence, technology use, migration and social involvement. Portugal is part of this group of countries since 1996 (www.aventurasocial.com).

\section{Data Analysis}

Descriptive statistics, including frequencies, means and standard deviations, were performed to characterize the participants and gender and school grades differences were analysed using Chisquare and ANOVA tests. The level for statistical significance was set at $p<.05$.

The associations between the independent variables (gender, socioeconomic status, condom use, HIV test, body perception, physical activity, smoking tobacco on a daily basis, academic performance, truancy, bullying at school, emotional insensitivity and quality of life) and the dependent variable (having had SI under the influence of alcohol or drugs) were determined using multivariate logistic regression analysis. Odds ratios (OR) and $95 \%$ confidence intervals (CI) were calculated for all independent variables. Only significant results were discussed. Analyses and statistical procedures were carried out in the Statistical Package for Social Sciences program (SPSS, version 24.0 for Windows). 


\section{Research Results}

Differences between Genders and School Grades and Sexual Behaviours in Portuguese Adolescents

The majority of adolescents reported never having had SI $(n=4175 ; 77.0 \%)$, namely girls $(n=2343 ; 80.0 \%)$ and 8 th graders $(n=2294 ; 88.7 \%)$. Among those who stated having already had SI, they referred having had their first SI at 14.58 years old $(S D=1.49)$, most mentioned having used condom at last SI ( $n=822 ; 65.9 \%)$, not having had SI associated to alcohol or drugs $(n=812 ; 85.5 \%)$, and not having been tested for HIV $(n=893 ; 85.6 \%)$.

Some statistical significant differences were found regarding sexual behaviours: boys referred having had their first SI at an earlier age than female (male: $M=14.27, S D=1.62$; female: $M=14.92$, $S D=1.24)\left(F_{(1,1246)}=63.725, p=.000\right)$, and boys more frequently reported having used condom at last SI $(\chi 2(1)=4,621 ; p<.05)$ and having had SI under the influence of alcohol or drugs $(\chi 2(1)$ $=23,155 ; p<.0001)$; and younger teenagers ( $8^{\text {th }}$ graders) referred having had their first SI at an earlier age than older teenagers ( $10^{\text {th }}$ and $12^{\text {th }}$ graders $)\left(8^{\text {th }}\right.$ graders: $M=13.29, S D=1.51 ; 10^{\text {th }}$ graders: $M=14.51, S D=1.28 ; 12^{\text {th }}$ graders: $\left.M=15.30, S D=1.11\right)\left(F_{(2,1246)}=243.239, p=.0001\right)$ and younger teenagers more frequently reported than older teenagers ( $10^{\text {th }}$ and $12^{\text {th }}$ graders) having had SI under the influence of alcohol or drugs $(\chi 2(2)=11.937 ; p<.01)$. Older teenagers reported having already had SI more often than younger teenagers $\left(8^{\text {th }}\right.$ and $10^{\text {th }}$ graders $)\left(\chi^{2}(1)=592.248 ; p<.0001\right)$.

\section{Table 2}

Differences between Genders and School Grades and Sexual Behaviours in Portuguese Adolescents $(N=5695)^{l}$

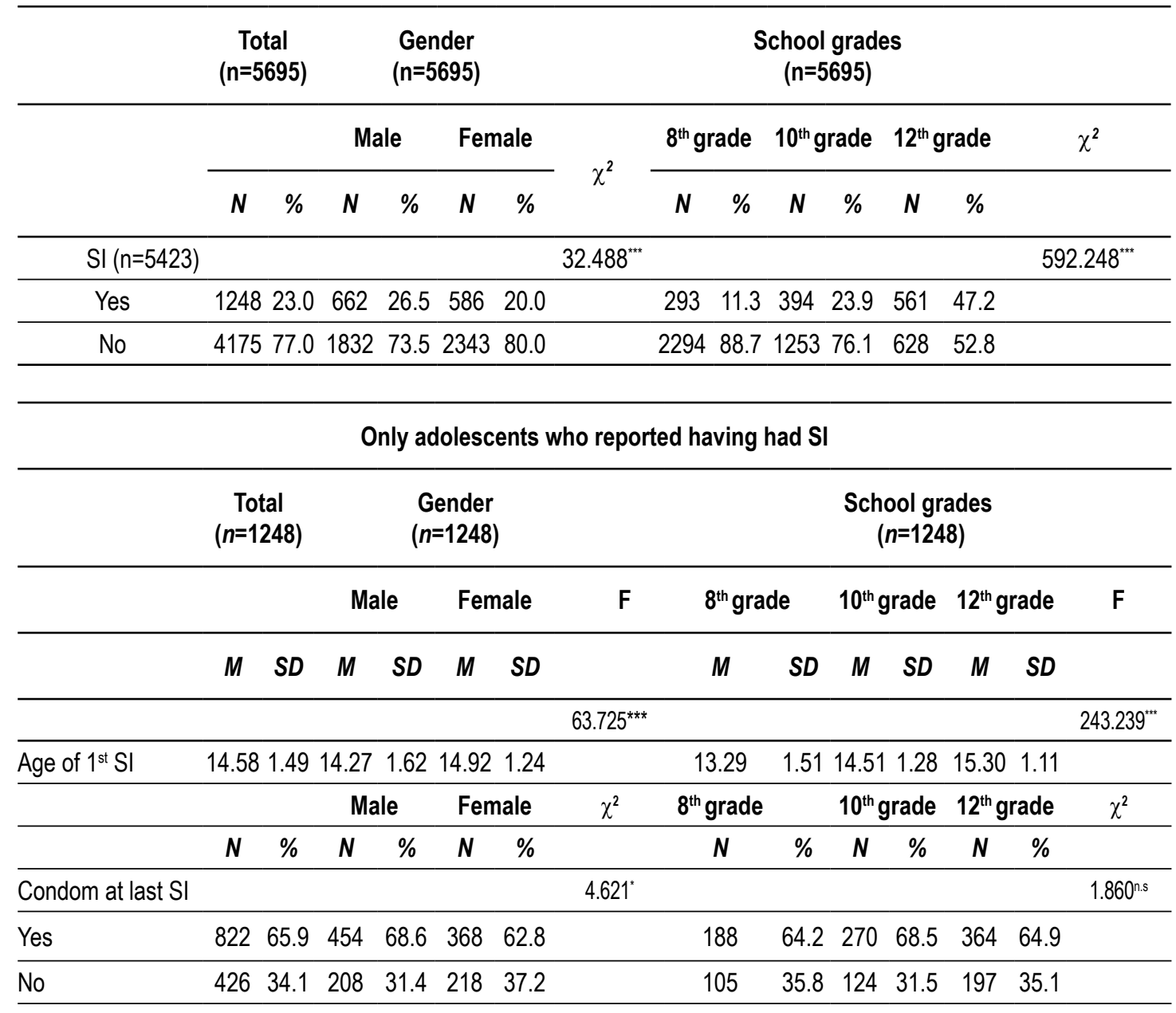


Only adolescents who reported having had SI

\begin{tabular}{|c|c|c|c|c|c|c|c|c|c|c|c|c|c|c|}
\hline & \multicolumn{2}{|c|}{$\begin{array}{c}\text { Total } \\
(n=1248)\end{array}$} & \multicolumn{4}{|c|}{$\begin{array}{l}\text { Gender } \\
(n=1248)\end{array}$} & \multirow{3}{*}{$F$} & \multicolumn{7}{|c|}{$\begin{array}{l}\text { School grades } \\
\qquad(n=1248)\end{array}$} \\
\hline & & & \multicolumn{2}{|c|}{ Male } & \multicolumn{2}{|c|}{ Female } & & \multicolumn{2}{|c|}{$8^{\text {th }}$ grade } & \multicolumn{2}{|c|}{$10^{\text {th }}$ grade } & \multicolumn{2}{|c|}{$12^{\text {th }}$ grade } & \multirow[t]{2}{*}{$\mathbf{F}$} \\
\hline & $M$ & $S D$ & $M$ & $S D$ & $M$ & $S D$ & & $M$ & $S D$ & $M$ & $S D$ & $M$ & $S D$ & \\
\hline $\begin{array}{l}\text { SI associated to } \\
\text { drugs or alcohol }\end{array}$ & & & & & & & $23.155^{\prime \prime \prime}$ & & & & & & & $11.937^{*}$ \\
\hline Yes & 138 & 14.5 & 96 & 20.0 & 42 & 9.0 & & 42 & 22.3 & 35 & 11.6 & 61 & 13.3 & \\
\hline No & 812 & 85.5 & 385 & 80.0 & 427 & 91.0 & & 146 & 77.7 & 267 & 88.4 & 399 & 86.7 & \\
\hline HIV Test & & & & & & & $0.001^{\mathrm{ns}}$ & & & & & & & $4.190^{n . s}$ \\
\hline Yes & 150 & 14.4 & 78 & 14.4 & 72 & 14.3 & & 41 & 18.4 & 40 & 12.2 & 69 & 14.0 & \\
\hline No & 893 & 85.6 & 463 & 85.6 & 430 & 85.7 & & 182 & 81.6 & 287 & 87.8 & 424 & 86.0 & \\
\hline
\end{tabular}

\section{Factors Associated to Unhealthy Sexual Behaviour among Portuguese Adolescents}

A logistic regression analysis was performed using the enter method to evaluate the predictive factors for SI under the influence of alcohol or drugs. Possible predictor independent variables were condom use at last SI, HIV test, body image, doing physical exercise at least 60 minutes in the previous week, tobacco consumption, academic performance, truancy, being involved in bullying, emotional insensitivity, and quality of life, as well as gender and socioeconomic status.

An adjusted model (Hosmer and Lemeshow $\chi^{2}=5.558$ (8) $p=.697$ ) was obtained and the regression equation explained $28 \%$ of variance (Nagelkerke $R^{2}=0.275$ ) and $85.8 \%$ of the cases of having engaged in SI under the influence of alcohol or drugs.

In this model the condition of "having engaged in SI under the influence of alcohol or drugs" is explained by the variables gender (2.0 times greater likelihood) [OR 1.99; 95\% CI 1.23-3.24; $p$ $<.01$ ], SES (0.6 times greater likelihood) [OR 0.63; 95\% CI 0.41-0.97; $\mathrm{p}=0.038$ ], condom use (1.6 times greater likelihood)[OR 1.61; 95\% CI 1.03-2.52; $p<.05$ ], HIV test (1.9 times greater likelihood) [OR 1.91; 95\% CI 1.11-3.29; $p<.05$ ], body image (2.0 times greater likelihood) [OR 2.02; 95\% CI 1.17-3.49; $p<.05$ ], smoking (0.3 times greater likelihood) [OR 0.32; 95\% CI 0.20-0.50; $p$ $<.01$ ], emotional insensitivity (1.2 times greater likelihood) [OR 1.17; 95\% CI 1.11-1.24; $p<.01$ ] and quality of life (0.9 times greater likelihood) [OR 0.96; 95\% CI 0.93-0.98; $p<.01$ ].

This is to say that the likelihood of having engaged in SI under the influence of alcohol or drugs is greater for boys and those subjects who reported not having used condom at last SI, not being HIV tested, considering themselves fat, smoking daily, having higher insensitivity and a lower perception of quality of life.

\section{Table 3}

Factors Associated with SI under the Influence of Alcohol or Drugs and Having Had Alcohol or Drugs in Portuguese Adolescents ( $N=1248)$

\begin{tabular}{lccccc}
\hline & $\boldsymbol{\beta}$ & $\mathrm{SE}$ & $\mathrm{OR}$ & $95 \%$ IC & $\boldsymbol{p}$ \\
\hline Gender & .691 & .247 & 1.996 & $(1.229-3.242)$ & .005 \\
\hline Socioeconomic status (SES) - high & .455 & .219 & 0.634 & $(0.413-0.974)$ & .038 \\
\hline
\end{tabular}




\begin{tabular}{lccccc}
\hline & $\boldsymbol{\beta}$ & SE & OR & $95 \%$ IC & $\boldsymbol{p}$ \\
\hline Condom use at last SI - no & .478 & .227 & 1.613 & $(1.034-2.515)$ & .035 \\
\hline HIV test - no & .646 & .279 & 1.908 & $(1.106-3.294)$ & .020 \\
\hline Body image - fat & .704 & .280 & 2.021 & $(1.168-3.497)$ & .012 \\
\hline Physical activity - 60 minutes previous week & -.281 & .332 & 0.755 & $(0.394-1.448)$ & .398 \\
\hline Smoking tobacco - on a daily basis & 1.139 & .230 & 0.320 & $(0.204-0.502)$ & $<.001$ \\
\hline Academic performance & -.538 & .323 & 0.584 & $(0.310-1.100)$ & .096 \\
\hline Truancy & -.138 & .224 & 0.871 & $(0.562-1.351)$ & .539 \\
\hline Bullying at school & -.085 & .290 & 0.918 & $(0.520-1.620)$ & .768 \\
\hline Emotional insensitivity - high & .159 & .030 & 1.173 & $(1.106-1.243)$ & $<.001$ \\
\hline Quality of life (KIDS) - low & -.045 & .014 & 0.956 & $(0.930-0.984)$ & .002 \\
\hline
\end{tabular}

OR: adjusted odds ratios for all table variables; Cl: confidence interval

\section{Discussion}

Findings show that the majority of 8th, 10th and 12th grade Portuguese adolescents have never had SI and among those who said they had, most stated having used condom at last SI and not having had SI under the influence of alcohol or drugs. Although the majority reported safe sexual behaviours, a significant minority - worthy of professional attention, referred not having used condom at last SI and having had SI under the influence of alcohol or drugs. These two risk behaviours have increased in comparison to the previous HBSC study $\left(2018-33.6 \%\right.$ and $17.0 \% ; 2014-29.6 \%$ and $15.9 \%$ of $8^{\text {th }}$ and $10^{\text {th }}$ graders, respectively), therefore these need to be understood and require intervention. One possible explanation for these results may be negligence in sexual education. Despite the existence of laws that make sexual education in school context compulsory in every school grade, recently it has been reduced to the contents that are part of school subjects, minimizing adolescents' opportunities to develop the personal and social skills that are the basis for all healthy behaviours, including those related to sexuality. Another explanation for these unhealthy sexual behaviours may be the reduction of AIDS campaigns, which may be a result of the evolution of AIDS into a chronic disease and no longer a fatal disease, consequently contributing to the downgrading of the importance of prevention.

The analysis of differences between genders and school grades and sexual behaviours in Portuguese adolescents resulted in several findings: boys reported having used condom more frequently than girls, but they were also the ones who reported having engaged in SI under the influence of alcohol or drugs; and younger adolescents $\left(8^{\text {th }}\right.$ graders) reported having engaged in SI under the influence of alcohol or drugs much more frequently than older students ( $10^{\text {th }}$ and $12^{\text {th }}$ graders).

In addition, the study of the factors associated to having had SI under the influence of alcohol identified boys, adolescents with a higher SES, those who did not use condom at last SI, those who did not get tested for HIV, think of themselves as fat, smoke every day, have lower emotional insensitivity, and reported less quality of life as the adolescents who more often reported this risk behaviour. These results are accounted for by literature since illegal drugs, tobacco consumption, alcohol consumption, history of sexual abuse, and bad academic performance, among others, are identified as behaviours associated to unhealthy sexual behaviours (Cruzeiro et al., 2010) and imply that the intervention to be implemented is tailored specifically to these groups.

As such, a much broader area of education than sexuality education is needed; Health Education may be a much more adequate answer as adolescents get involved in multiple risk behaviours that go beyond the sexual ones. Consequently, they need their personal and social skills to be addressed and developed in order to enhance their abilities to adopt overall protective behaviours (self-regulation, negotiation, resisting peer pression, etc.) and therefore they need interventions that aim to promote healthy lifestyles and quality of life instead of being subjected to interventions that are limited to prevent risk behaviours, that is achieving prevention throughout positive emotional, cognitive and behavioural competence promotion. 
OF PSYCHOLOGY

IN THE $21^{\text {st }}$ CENTURY

Vol. 15, No. 2, 2021

80 Schools are often seen as places where all children and adolescents can have access to life changing opportunities through systematic interventions that are able to promote self-management strategies (Department of Health and Department of Education, 2017) and overall well-being (Hayes et al, 2019).

Given the scope of this approach, it is crucial to involve not only the individual and the school, but all the structures that can be activated to support teenagers (Morgan, et al., 2010).

\section{Conclusions and Implications}

These results may represent significant changes in educational and health policies, directing these towards the development of personal and social skills, the importance of adolescents' quality of life and the activation of all the support structures where adolescents are involved and that are somewhat responsible for promoting a healthy lifestyle. Adolescents must be encouraged to lead healthy lifestyles in all the settings they live in. Schools must be responsible for a comprehensive approach, thus promoting adolescents' quality of life, and consequently their physical and mental health.

Besides all the known factors that are more or less associated to healthy and unhealthy risk behaviours, namely sexual risk behaviours, the world is now facing an emerging challenge due to the Covid-19 outbreak with its unknown impacts. It is an evolving situation that is transforming the lifestyles of the world population, adolescents included. Despite all the uncertainties that still exist about how it spreads and the measures for protection, health authorities urge people to avoid close contact and wear a face mask, among other measures, which may change the way people interact in general. If that may have dramatic consequences for the adult population, adolescents' lifestyles and socialization may suffer greatly with this since they are in a stage in which avoiding contact may hinder the development of their social skills in the future.

These are important messages addressing public policies in the area of education and health that will allow youth to be more participative, with access to a broad range of alternatives, more selffulfilled, happier, healthier and less prone to inequality.

\section{References}

Collins, K. A,. \& Dozois, D. J. A. (2008). What are the active ingredients in preventative interventions for depression? Clinical Psychology: Science and Practice, 15(4), 313-330. https://psycnet.apa.org/doi/10.1111/j.1468-2850.2008.00143.x

Cruzeiro, A., Souza, L., Silva, R., Pinheiro, R., Rocha, C., \& Horta, B. (2010). Comportamento sexual de risco: fatores associados ao número de parceiros sexuais e ao uso de preservativo em adolescentes [Risky sexual behavior: Factors associated with the number of sexual partners and condom use in adolescentes]. Revista Ciência \& Saúde Coleiva, 15(1). http://www.cienciaesaudecoletiva.com.br/ artigos/comportamento-sexual-de-risco-fatores-associados-ao-numero-de-parceiros-sexuais-e-aouso-de-preservativo-em-adolescentes/1483?id=1483

Department of Health and Department of Education. (2017). Transforming children and young people's mental health. Provision: A Green Paper. London.

DGS-Direção-geral dasaúde(2018).Infeção VIHeSIDA,Desafioseestratégias[HIVandAIDSinfection, challengesandstrategies]. https://www.dgs.pt/portal-da-estatistica-da-saude/diretorio-de-informacao/diretorio-de-informacao/por-serie-980619pdf.aspx?v=\%3d\%3dDwAAAB\%2bLCAAAAAAABAArySzItzVUy81MsTU1MDAFAHzFEfkPAAAA

Gaspar, T, Tomé, G., Gómez-Baya, D., Botelho, F., Cerqueira, A., Borges, A. \& Matos, M.G. (2019). O Bem estar e a saúde mental dos adolescentes portugueses [The well-being and mental health of Portuguese adolescentes]. Revista da Psicologia da Criança e do Adolescente, 10(1), 17-27.

Hayes, D., Moore, A., Stapley, E., Humphrey, N., Mansfield, R., Santos, J., Ashworth, E., Patalay, P., Bonin, E., Rasmus Boehnke, J., \& Deighton, J. (2019). School-based intervention study examining approaches for well-being and mental health literacy of pupils in Year 9 in England: study protocol for a multischool, parallel group cluster randomised controlled trial (AWARE). BMJ Open, 9(8), Article e029044. http://dx.doi.org/10.1136/bmjopen-2019-029044

Inchley, J. C., Currie, D. B., Young, T., Samdal, O., Torsheim, T., Augustson, L., ... Barnekow, V. (Eds.) (2016). Growing up unequal: Gender and socioeconomic differences in young people's health and well- 
being: Health Behaviour in School-aged Children (HBSC) study: International report from the 2013/2014 survey). WHO Regional Office for Europe.

López, F., \& Fuertes, A. (1999). Para compreender a sexualidade [To understand sexuality]. Associação para o Planeamento da Família.

Madkour, A. S., Farhat, T., Halpem, C. T., Godeau, E., \& Gabhainn, S.N. (2010) Early adolescent sexual initiation as a problem behaviour: A comparative study of five nations. Journal of Adolescent Health, 47(4), 389-398.

Matos, M. G., Simões, C., Camacho, I., Reis, M., \& Equipa Aventura Social (2015). A saúde dos adolescentes em tempo de recessão - Dados nacionais do estudo HBSC de 2014 - Relatório do estudo HBSC 2014 [Adolescent health in a time of recession - 2014 National HBSC study data - 2014 HBSC Study Report. http://aventurasocial.com/arquivo/1437158618_RELATORIO\%20HBSC\%202014e.pdf

Matos, M. G., \& Equipa Aventura Social (2018). A saúde dos adolescentes após a recessão - Dados nacionais do estudo HBSC de 2018 ebook [Adolescent health after the recession - National data from the 2018 HBSC study ebook], http://aventurasocial.com/publicacoes/publicacao_1545534554.pdf

Morgan, A., Davies, M., \& Ziglio, E. (2010). Health assets in a global context: Theory, methods, action. Springer.

Roberts, C., Freeman J., Samdal, O., Schnohr C., Looze, M., Nic Gabhainn, S., Iannotti, I., Rasmussen M., \& Matos, M. G. in the International HBSC study group (2009). The Health Behaviour in School-aged Children (HBSC) study: Methodological developments and current tensions. International Journal of Public Health, 54(Suppl. 2), 140-150.

Taylor, R., Oberle, E., Durlak, J. A., \& Weissberg, R. P. (2017). Promoting positive youth development through school-based social and emotional learning interventions: A meta-analysis of follow-up effects. Child Development, 88(4), 1156-1171.

UNAIDS (2018). Joint United Nations Programme on HIV/AIDS. UNAIDS DATA 2018. http://www.unaids.org/en/resources/documents/2018/unaids-data-2018

UNICEF (2018). United Nations Children's Fund, Women: At the heart of the HIV response for children. UNICEF.

\begin{tabular}{cl} 
Lúcia Ramiro & PhD, Teacher, Researcher at ISAMB/ Faculty of Medicine, University of Lisbon, \\
(Corresponding author) & Portugal. \\
& E-mail: lisramiro@sapo.pt \\
& Website: https://aventurasocial.com \\
& ORCID: https://orcid.org/0000-0002-0065-1757 \\
\hline \multirow{2}{*}{ Marta Reis } & PhD, Clinical and Health Psychologist, Researcher, Faculty of Human Kinetics, \& \\
& ISAMB/Faculty of Medicine, University of Lisbon, Portugal. \\
& E-mail: reispsmarta@gmail.com \\
& Website: https://aventurasocial.com \\
& ORCID: https://orcid.org/0000-0002-9351-6617 \\
& PhD, Full Professor, Clinical and Health Psychologist, Researcher, ISAMB/ Faculty \\
& of Medicine, University of Lisbon, Portugal. \\
& E-mail: mmatos@fmh.utl.pt \\
& Website: https://aventurasocial.com \\
Margarida Gaspar de Matos: https://orcid.org/0000-0003-2114-2350
\end{tabular}

